\title{
Humic acid-mediated visible-light degradation of phenol on phosphate-modified and Nafion-modified $\mathrm{TiO}_{2}$ surfaces
}

\author{
Longhui Zheng a, Xiaojuan Yu a, Mingce Long a,b,*, Qilin Li c \\ a School of Environmental Science and Engineering, Shanghai Jiao Tong University, Shanghai 200240, China \\ b Key Laboratory for Thin Film and Microfabrication of the Ministry of Education, Shanghai Jiao Tong University, Shanghai 200240, China \\ c Department of Civil and Environmental Engineering, Rice University, Houston, Texas 77005, United States
}

\section{A R T I C L E I N F O}

\section{Article history:}

Received 9 October 2017

Accepted 30 October 2017

Published 5 December 2017

\section{Keywords:}

Titanium dioxide

Humic acid

Nafion

Phosphate

Surface modification

\begin{abstract}
A B S T R A C T
Although humic acid (HA) can inhibit $\mathrm{TiO}_{2}$ photocatalysis, it can sensitize $\mathrm{TiO}_{2}$ and induce significant visible-light (VL) activity in phenol degradation. This favorable effect of $\mathrm{HA}$ was negligible on phosphate-modified $\mathrm{TiO}_{2}\left(\mathrm{P}-\mathrm{TiO}_{2}\right)$, but significantly stronger on Nafion-modified $\mathrm{TiO}_{2}\left(\mathrm{Nf}-\mathrm{TiO}_{2}\right)$. The reaction rate constants for phenol degradation on $\mathrm{Nf}_{-} \mathrm{TiO}_{2}$ increased from $(0.003 \pm 0.001)$ to $(0.025 \pm 0.003) \mathrm{min}^{-1}$ when the reaction was performed in the presence of $20 \mathrm{mg} / \mathrm{L} \mathrm{HA}$. The different effects of $\mathrm{HA}$ on $\mathrm{P}_{-}-\mathrm{TiO}_{2}$ and $\mathrm{Nf}-\mathrm{TiO}_{2}$ photocatalysis cannot be attributed to adsorption changes, because the adsorption capacities of $\mathrm{P}_{-} \mathrm{TiO}_{2}$ and $\mathrm{Nf}-\mathrm{TiO}_{2}$ were only slightly lower than that of $\mathrm{TiO}_{2}$ at an initial HA concentration of $20 \mathrm{mg} / \mathrm{mL}$. Scavenger tests, electron paramagnetic resonance spectroscopy, and $\mathrm{H}_{2} \mathrm{O}_{2}$ detection were taken to understand the low $\mathrm{VL}$ activity of the $\mathrm{P}-\mathrm{TiO}_{2} / \mathrm{HA}$ suspension. The main active species for phenol degradation in the $\mathrm{TiO}_{2}$ and $\mathrm{Nf}_{-} \mathrm{TiO}_{2}$ suspensions were superoxide radicals. There were negligible amounts of superoxide radicals in the $\mathrm{P}-\mathrm{TiO}_{2} / \mathrm{HA}$ suspension, possibly because a direct four-electron oxygen reduction reaction occurred. The better VL activity of $\mathrm{Nf}-\mathrm{TiO}_{2}$ was rationalized on the basis of Mott-Schottky and electrochemical impedance plots. Nafion modification resulted in cathodic shifts of the energy band positions, increased electron density, and less resistance to electron transfer across the interface between $\mathrm{TiO}_{2}$ and electrolytes. All these factors facilitated electron transfer and improved the production of active species. Phosphate modification therefore did not improve the $\mathrm{VL}$ response of $\mathrm{HA}$ sensitized $\mathrm{TiO}_{2}$, and low concentrations of HA can facilitate VL photocatalytic degradation of organic pollutants on Nafion surface-modified $\mathrm{TiO}_{2}$.
\end{abstract}

(C) 2017, Dalian Institute of Chemical Physics, Chinese Academy of Sciences. Published by Elsevier B.V. All rights reserved.

\section{Introduction}

Photocatalytic water treatment has shown great potential as a cost-efficient technique for the removal of recalcitrant organic pollutants in water [1-6]. Although hundreds of new photocatalysts have been developed by using approaches such as engineered nanoarchitectures or band energy structures
[7-13], $\mathrm{TiO}_{2}$ is still the most promising material for water purification because of its advantages such as robustness, low cost, and safety $[14,15]$. Photocatalytic processes and their reaction kinetics depend greatly on the surface properties of $\mathrm{TiO}_{2}$, therefore, surface modification has been intensively investigated in $\mathrm{TiO}_{2}$-mediated photocatalysis [16-21]. Among species that can be used to alter the surface properties of $\mathrm{TiO}_{2}$, Nafion

\footnotetext{
* Corresponding author. Tel: +86-21-54747354; Fax: 86-21-54740825; E-mail: long_mc@sjtu.edu.cn

This work was supported by the National Natural Science Foundation of China (21377084), Special Fund for Agro-Scientific Research in the Public Interest (201503107), and Shanghai Municipal International Cooperation Foundation (15230724600). 
and phosphate are two readily available candidates. Nafion, which is an anionic perfluorinated polymer consisting of a hydrophobic polytetrafluoroethylene backbone and side chains with hydrophilic sulfonate groups, is chemically and photochemically inert under both oxidative and reductive conditions [22-24]. Nafion-modified $\mathrm{TiO}_{2}\left(\mathrm{Nf}-\mathrm{TiO}_{2}\right)$ has shown significantly enhanced photocatalytic activity in the degradation of cationic substrates (e.g., herbicides, dyes, and tetramethylammonium) [25-30]. This could be because of improved adsorption of cationic species at ion-exchange sites in Nafion [25-30]. The photocatalytic degradation of organic compounds in water can be influenced by coexisting inorganic anions (e.g., phosphate) that can strongly bind to the $\mathrm{TiO}_{2}$ surface and alter the surface charge properties [31]. It has been reported that phosphate-modified $\mathrm{TiO}_{2}\left(\mathrm{P}-\mathrm{TiO}_{2}\right)$ positively influences degradation of compounds that adsorb poorly on $\mathrm{TiO}_{2}$ by increasing the production of hydroxyl radicals; however, it decreases the degradation of strongly adsorbing compounds [31-33]. The enhanced performance of phosphate-modified $\mathrm{TiO}_{2}$ has also been attributed to facilitated electron transfer and improved oxygen adsorption [21,34,35]. Although photocatalytic reactions involving band gap excitation of phosphate- or Nafion-modified $\mathrm{TiO}_{2}$ have been reported, there have been few studies of the photoreactions of these modified $\mathrm{TiO}_{2}$ materials under ambient conditions with coexisting dissolved natural organic matter (NOM) and under daylight irradiation.

NOM, which is pervasive in water, always decreases the degradation efficiency of target prior pollutants by photocatalysis or other advanced oxidation processes [32,36-39]. This inhibitory effect is mainly attributed to competitive reactions with reactive oxygen species (ROS) and competitive adsorption between NOM and target pollutants [32,39]. Surface modification to alter the adsorption of NOM and modulate photocatalytic processes has shown great potential in counteracting inhibitory effects [32]. However, ROS can be photochemically produced in aerobic water containing NOM, and this facilitates the photosensitized degradation of waterborne organic pollutants [40-45]. Photoionization of NOM by light of wavelength $300-500 \mathrm{~nm}$ can produce triplet states $\left({ }^{3} \mathrm{NOM}^{*}\right)$ and hydrated electrons $\left(\mathrm{e}^{-}\right)[43,46]$. Vinodgopal et al. [47] reported charge injection from excited NOM into semiconductor colloids; this indicates that electrons photoproduced from NOM can be trapped by semiconductor nanoparticles, to produce superoxide radicals $\left(\mathrm{O}_{2}{ }^{-}\right)$through a single-electron oxygen reduction reaction (ORR). NOM therefore favorably affects $\mathrm{TiO}_{2}$ photocatalysis by serving as sensitizers that extend the photocatalytic function to the visible-light (VL) range. It is a challenge to strengthen this favorable effect but avoid the inhibitory effect of NOM, and achieving this is important in pilot studies of $\mathrm{TiO}_{2}$ photocatalytic water treatment.

Humic acid (HA), a representative NOM containing abundant phenolic, hydroxyl, and carboxylic groups, adsorbs strongly on $\mathrm{TiO}_{2}$ with a high Langmuir binding constant (0.12-0.90 L mg-1) [48]. In this study, we compared the sensitizing effects of HA on Nafion- and phosphate-modified $\mathrm{TiO}_{2}$ materials under VL irradiation. Phenol was used as a model pollutant to probe the photocatalytic activity because of its non-ionic properties and negligible adsorption on $\mathrm{TiO}_{2}$. The mechanism of the effect of $\mathrm{HA}$ on the two modified $\mathrm{TiO}_{2}$ materials was explored based on analyses of the degradation kinetics, adsorption, main active species, and semiconductor properties. Clarification of the effects of surface species on the VL activity of $\mathrm{TiO}_{2}$ in water containing NOM is important in understanding the photochemical activity and toxicity of nanoparticles, and will help in the development of effective photocatalytic materials for pilot studies of water purification.

\section{Experimental}

\subsection{Materials}

Humic acid sodium (HA), furfuryl alcohol (FFA), phenol, $\mathrm{NaH}_{2} \mathrm{PO}_{4}$, isopropyl alcohol (IPA), $p$-benzoquinone (BQ), and $N, N$-diethyl- $p$-phenylenediamine (DPD) were all obtained from Sigma Aldrich, USA. Nafion (5 wt\% solution in a mixture of ethanol, 1-propanol, and water) was purchased from the Dupont Co., Ltd., USA. 5,5-Dimethy-l-pyrroline $N$-oxide (DMPO) was obtained from the Adamas Co., Ltd., China. Peroxidase (POD, horseradish, RZ > 1.5) was obtained from the Sangon Biotech Co., Ltd., China All other reagents were purchased from the Shanghai Chemical Reagent Co., Ltd., China.

Commercial Degussa P25 $\mathrm{TiO}_{2}$ (a mixture of $71 \%$ anatase and $29 \%$ rutile) was used for all tests. To avoid desorption, $\mathrm{P}^{-} \mathrm{TiO}_{2}$ was obtained by photocatalytic degradation in a suspension of $\mathrm{TiO}_{2}$ and $2 \mathrm{mmol} / \mathrm{L} \mathrm{NaH} \mathrm{PO}_{4}$. Nf- $\mathrm{TiO}_{2}$ was prepared using a previously reported method [28]. Briefly, Nafion solution and $\mathrm{TiO}_{2}$ powder, at a ratio of $50 \mathrm{mg}$ (Nafion)/g $\left(\mathrm{TiO}_{2}\right)$, were added to deionized water $(10 \mathrm{~mL})$. The suspension was stirred for $6 \mathrm{~h}$ to ensure homogeneous coating of the $\mathrm{TiO}_{2}$ nanoparticles with Nafion. The product was dried in a vacuum oven at $30^{\circ} \mathrm{C}$ for $24 \mathrm{~h}$ to give $\mathrm{Nf}-\mathrm{TiO}_{2}$.

\subsection{Photocatalytic degradation experiments}

The light source was a 500-W xenon lamp with a $420 \mathrm{~nm}$ cutoff filter and a filter to remove infrared light. In the phenol degradation tests, a suspension of the photocatalyst $(0.5 \mathrm{~g} / \mathrm{L})$ was mixed with phenol $(10 \mathrm{mg} / \mathrm{L})$ in a $50 \mathrm{~mL}$ quartz vessel; various amounts of HA were then added. In all the tests, the initial $\mathrm{pH}$ values of the suspensions were carefully adjusted to 3.0 with $\mathrm{HClO}_{4}$ to minimize desorption of phosphate or Nafion from $\mathrm{TiO}_{2}$. The suspension was kept in the dark at room temperature for $30 \mathrm{~min}$ to achieve adsorption-desorption equilibrium, and was then illuminated to start the photocatalytic degradation. At predetermined times, samples were collected and filtered through a $0.45 \mu \mathrm{m}$ polyethersulfone (PES) filter. The residual phenol concentrations were determined using a high-performance liquid chromatography system (LC-2010AHT, Shimadzu) equipped with a C-18 column. A binary mixture of phosphoric acid solution $(0.1 \mathrm{wt} \%)$ and methanol at a volumetric ratio of 70:30 was used as the mobile phase, and the detection wavelength was $270 \mathrm{~nm}$. Apparent first-order degradation rate constants $(k)$ were obtained for all photocatalytic processes. The ratio $(R)$ between the reaction 
rate constants in the absence $\left(k_{0}\right)$ and presence of HA $(k)$ was used as a measure of the inhibitory or favorable effect of HA. The concentration of HA in all tests, unless specified, was 20 $\mathrm{mg} / \mathrm{L}$.

The concentration of $\mathrm{H}_{2} \mathrm{O}_{2}$ in the illuminated suspension was determined using a modified DPD-POD method [49,50]. Briefly, the solution obtained after filtration $(1 \mathrm{~mL})$ was transferred to a $10 \mathrm{~mL}$ volumetric flask and mixed with phosphate buffer ( $3 \mathrm{~mL}, 0.5 \mathrm{~mol} / \mathrm{L}, \mathrm{pH}=6)$. Then DPD solution ( $50 \mu \mathrm{L}, 10$ $\mathrm{mg} / \mathrm{mL}$ ) and POD solution ( $50 \mu \mathrm{L}, 1 \mathrm{mg} / \mathrm{mL}$ ) were pipetted into the mixture and deionized water $(10 \mathrm{~mL})$ was added. The $\mathrm{H}_{2} \mathrm{O}_{2}$ concentration was obtained by measuring the absorbance at $551 \mathrm{~nm}$ (UV-vis spectrophotometer, T6-New Century, Purkinje General).

The electron paramagnetic resonance (EPR) signals for DMPO- $\mathrm{O}_{2} \cdot-$ adducts were recorded using an EPR spectrometer (MS 5000, Magent Tech), with DMPO as the spin trap. A catalyst suspension $(0.5 \mathrm{~g} / \mathrm{L})$ in methanol was irradiated for 5 min under VL in the presence of DMPO $(20 \mathrm{mmol} / \mathrm{L})$. A sample of the suspension (about $0.5 \mathrm{~mL}$ ) was removed, filtered through a $0.22 \mu \mathrm{m}$ PES filter, immediately transferred to a flat quartz EPR cell, and the EPR spectrum was recorded. The EPR settings were center field, $336 \mathrm{mT}$; sweep width, $10 \mathrm{mT}$; sweep time, 60 $\mathrm{s}$; modulation, $0.2 \mathrm{mT}$; resonance frequency, $9.464 \mathrm{GHz}$; and microwave power, $20 \mathrm{~mW}$. X-ray photoelectron spectroscopy (XPS) was performed using an AXIS Ultra DLD spectrometer (Kratos Analytical-A, Shimadzu) with a monochromatic Al $K_{\alpha}$ source $(1486.6 \mathrm{eV})$. $\mathrm{P}-\mathrm{TiO}_{2}$ samples for XPS were prepared by dispersing $\mathrm{TiO}_{2}$ in a $\mathrm{NaH}_{2} \mathrm{PO}_{4}$ solution $(2 \mathrm{mmol} / \mathrm{L})$. The solid was separated by filtration and freeze-dried.

\section{3. (Photo)electrochemical tests}

Electrochemical measurements were performed using a CHI $760 \mathrm{E}$ electrochemical system with a three-electrode cell. The light source was a 500-W xenon lamp with a cutoff filter $(\lambda>$ $420 \mathrm{~nm}$ ). A Pt plate and $\mathrm{Hg} / \mathrm{HgCl}_{2}$ electrode were used as the counter electrode and reference electrode, respectively. The working electrode was prepared by coating a slurry of the sample on a cleaned indium tin oxide glass substrate by the doctor blade method. The slurry was prepared by dispersing the powder sample $(0.2 \mathrm{~g})$ in absolute ethanol $(1 \mathrm{~mL})$. The coated electrodes were heated at $200{ }^{\circ} \mathrm{C}$ in air for $2 \mathrm{~h}$ to improve adhesion. In all the tests, the available surface area of the working electrode was $1 \mathrm{~cm}^{2}$.

Impedance-potential tests were performed in a three-electrode cell, using previously reported procedures [51]. The ac amplitude and frequency were set at $5 \mathrm{mV}$ and $1.5 \mathrm{kHz}$, respectively. Electrochemical impedance spectroscopy (EIS) was performed by applying an open circuit voltage bias $(0.2 \mathrm{~V})$ and were recorded over the frequency range $0.1-10^{5} \mathrm{~Hz}$ at an ac amplitude of $5 \mathrm{mV}$. The electrolyte for current-time and EIS tests was a $0.1 \mathrm{~mol} / \mathrm{L}$ sodium perchlorate solution of $\mathrm{pH}=3.5$, and for the impedance-potential tests it was a $0.5 \mathrm{~mol} / \mathrm{L}$ $\mathrm{Na}_{2} \mathrm{SO}_{4}$ aqueous solution of $\mathrm{pH}=5.5$. The electrolyte was purged with nitrogen for 20 min prior to each test and continuously purged during the measurements.

\subsection{Adsorption experiments}

$\mathrm{TiO}_{2}$ (25 mg) or $\mathrm{Nf}-\mathrm{TiO}_{2}$ (25 mg) was added to HA aqueous solutions ( $50 \mathrm{~mL}, 20,40$ or $60 \mathrm{mg} / \mathrm{L}$ ), and the suspension $\mathrm{pH}$ was adjusted to 3.0. To determine the effect of phosphate modification, HA solutions were prepared in the presence of 2 mmol/L phosphate solutions. The suspensions were stirred at $30{ }^{\circ} \mathrm{C}$ for $1 \mathrm{~h}$ to reach adsorption equilibrium. In time-dependence tests, samples were withdrawn at predetermined times. The concentration of HA was determined by measuring the absorbance at $254 \mathrm{~nm}$ and calibrating using standard samples.

\section{Results and discussion}

Fig. 1(a-c) show the effects of HA on VL degradation of phenol over $\mathrm{TiO}_{2}$ and surface-modified $\mathrm{TiO}_{2}$. About $26 \%$ $( \pm 0.9 \%)$ phenol was removed on pristine $\mathrm{TiO}_{2}$ by VL irradiation for $120 \mathrm{~min}$. This is attributed to the formation of phenolic complexes on the $\mathrm{TiO}_{2}$ surface, which enabled ligand-to-metal charge transfer in the VL range [52]. Unlike the inhibitory effect of $\mathrm{HA}$ in phenol degradation over $\mathrm{TiO}_{2}$ under UV irradiation [32], VL degradation of phenol was greatly enhanced in the presence of HA. The degradation rate constants for phenol increased to $(0.0104 \pm 0.0001) \mathrm{min}^{-1}$ at a HA concentration of 20 $\mathrm{mg} / \mathrm{L}$, about four times that in the absence of HA. This can be ascribed to the sensitizing effect of HA, which can absorb light below $500 \mathrm{~nm}$ and inject excited electrons into $\mathrm{TiO}_{2}$ to produce ROS. Even in the absence of $\mathrm{TiO}_{2}$ or other semiconductors, ROS can be produced by illuminating a HA solution $[43,45]$, and the presence of electron donors such as hydroxyaromatic compounds accelerate the generation of $\mathrm{O}_{2}{ }^{\bullet-}$ [42]. This explains why a $17 \%( \pm 0.5 \%)$ decrease in the amount of phenol was achieved in the presence of $20 \mathrm{mg} / \mathrm{L} \mathrm{HA}$ alone after irradiation for 120 min. The VL degradation rate of phenol on $\mathrm{TiO}_{2}$ (Fig. 1(b)) increased with increasing HA concentration. However, the improvement lessened with increasing HA concentration from 20 to $40 \mathrm{mg} / \mathrm{L}$. This can be ascribed to an inhibitory effect of HA and the saturation of occupied adsorption sites.

The Nf- $-\mathrm{TiO}_{2}$ and $\mathrm{P}-\mathrm{TiO}_{2}$ samples slightly changed the VL activity in phenol degradation compared to that of unmodified $\mathrm{TiO}_{2}$ (Fig. 1(a)). The phosphate and Nafion loadings were also investigated (Fig. S1). The results indicate that the catalysts with $50 \mathrm{mg}$ Nafion/g $\mathrm{TiO}_{2}$ and $2 \mathrm{mmol} / \mathrm{L}$ phosphate had the best VL activities. However, the effects of both loadings on the photocatalytic performance of $\mathrm{TiO}_{2}$ were low. HA strongly inhibited the VL degradation of phenol on $\mathrm{P}_{-} \mathrm{TiO}_{2}$, with an $R$ value of 0.51 , which is much less than 1 . This contradicts previous reports that under UV irradiation HA facilitated charge transfer and enhanced phenol degradation on phosphate-modified $\mathrm{TiO}_{2}$ [32]. This indicates that the mechanism of phenol photocatalytic degradation depends on the light source. The phosphate in the solution did not inhibit sensitization of degradation of phenol by HA alone (Fig. S2). However, HA (20 mg/L) significantly increased the $\mathrm{VL}$ degradation rates of phenol on $\mathrm{Nf}_{-} \mathrm{TiO}_{2}$. The reaction rate constant increased from $(0.003 \pm 0.001) \mathrm{min}^{-1}$ in the absence of HA to $(0.025 \pm 0.003) \mathrm{min}^{-1}$ in the presence of 

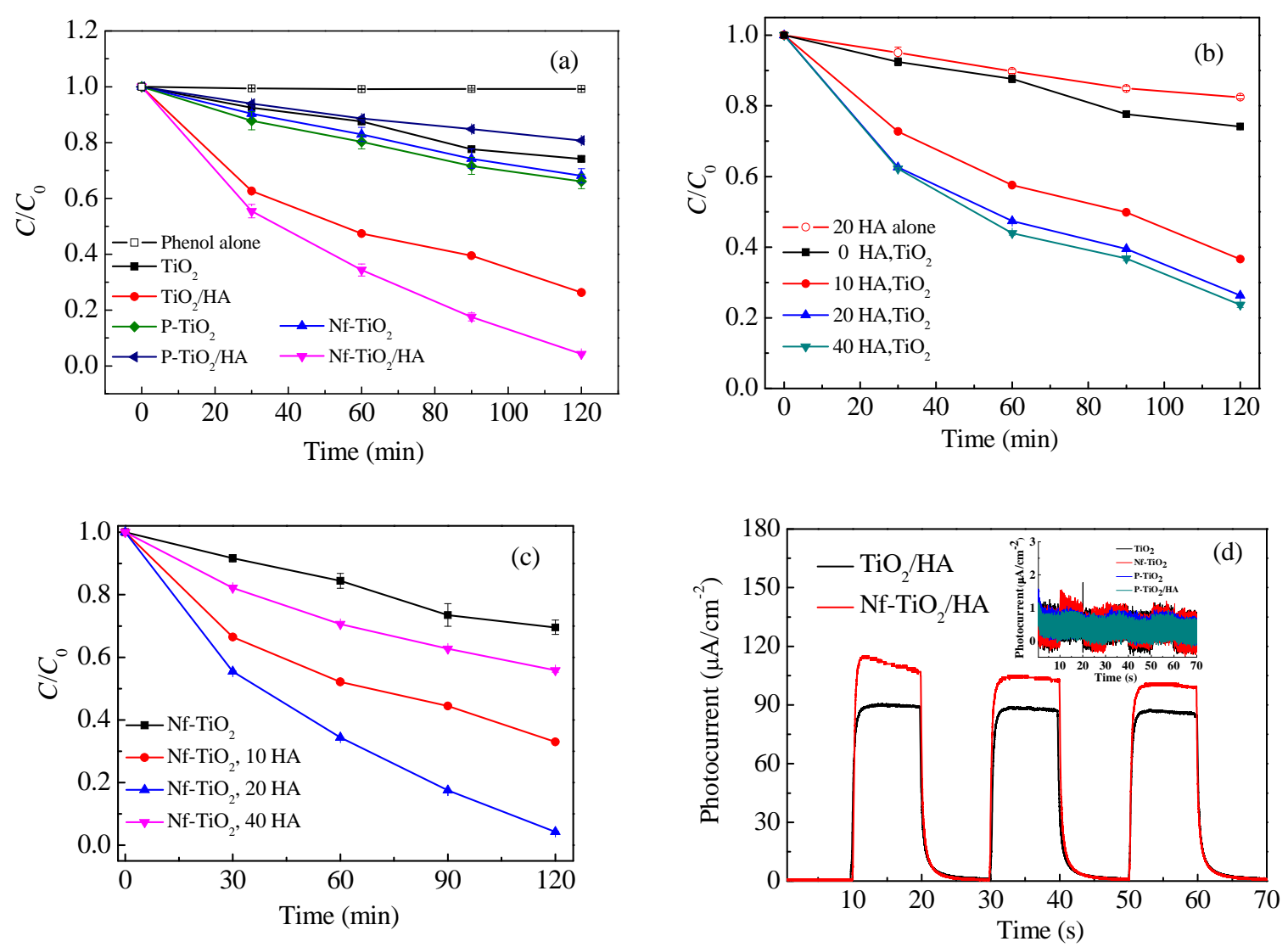

Fig. 1. (a) Phenol photocatalytic degradation on various photocatalysts in absence or presence of $\mathrm{HA}(20 \mathrm{mg} / \mathrm{L})$; effect of HA concentration on phenol

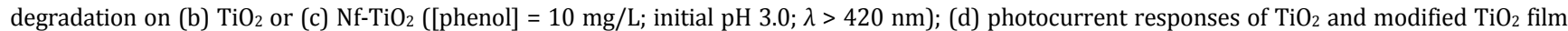
electrodes in absence or presence of $\mathrm{HA}(\lambda>420 \mathrm{~nm})$.

$20 \mathrm{mg} / \mathrm{L}$ HA. The factor $R$ is 7.8, which is much larger than that for pristine $\mathrm{TiO}_{2}(R=4.0$ at $20 \mathrm{mg} / \mathrm{L} \mathrm{HA})$. Moreover, the phenol removal efficiency was $96 \%( \pm 0.3 \%)$ after VL irradiation for $120 \mathrm{~min}$. The results of control tests performed at an initial $\mathrm{pH}$ of 6.0 suggest that the trends in the effect of HA were similar for $\mathrm{Nf}_{-}-\mathrm{TiO}_{2}$ and $\mathrm{P}_{-} \mathrm{TiO}_{2}$ under acidic and neutral conditions (Fig. S3). However, the phenol degradation rate decreased when the HA concentration was increased to $40 \mathrm{mg} / \mathrm{L}$ (Fig. 1(c)). This can be attributed to a concurrent inhibitory effect.

Enhancement of the VL activity of $\mathrm{Nf}^{-\mathrm{TiO}_{2}}$ by HA modification was confirmed by photocurrent measurements. The current-time curves for electrodes with various on-off cycles of intermittent irradiation are shown in Fig. 1(d). The inset in the figure shows that the photocurrent signal was negligible for all the electrodes in the absence of HA; this is consistent with the large band gap of $\mathrm{TiO}_{2}(\sim 3.2 \mathrm{eV})$. For the $\mathrm{P}_{-}-\mathrm{TiO}_{2}$ electrode in the presence of $\mathrm{HA}$, the photocurrents were also low, less than 1 $\mu \mathrm{A} / \mathrm{cm}^{2}$. Sensitization by HA induced a significant photocurrent for $\mathrm{TiO}_{2}\left(90 \mu \mathrm{A} / \mathrm{cm}^{2}\right)$, and an even higher photocurrent for $\mathrm{Nf}-\mathrm{TiO}_{2}\left(117 \mu \mathrm{A} / \mathrm{cm}^{2}\right)$. The better photocurrent response by $\mathrm{Nf}-\mathrm{TiO}_{2}$ indicates enhanced photoelectron generation and mobilization, which is consistent with a higher activity in phenol degradation under VL irradiation.

XPS was used to prove the presence of phosphate and Nafion on $\mathrm{P}_{-}-\mathrm{TiO}_{2}$ and $\mathrm{Nf}-\mathrm{TiO}_{2}$. The $\mathrm{P} / \mathrm{Ti}$ and $\mathrm{F} / \mathrm{Ti}$ ratios at the $\mathrm{TiO}_{2}$ surface were 0.05 and 1.3 , respectively. For $\mathrm{P}_{-} \mathrm{TiO}_{2}$, the asymmetric P $2 p$ spectrum (Fig. 2(a)) can be fitted by two peaks, at 132.8 and $133.7 \mathrm{eV}$. These can be assigned to monodentate coordination between surface Ti sites and $\mathrm{PO}_{4}{ }^{3-}$, with $\mathrm{P}$ in the pentavalent state [35]. For $\mathrm{F}_{-} \mathrm{TiO}_{2}$, the band centered at 688.8 $\mathrm{eV}$ (Fig. 2(b)) is assigned to the F signal from Nafion molecules [27]. The presence of adsorbed Nafion is confirmed by a peak at $535.4 \mathrm{eV}$ in the $01 s$ spectrum (Fig. S4), which corresponds to oxygen in the sulfonic acid group.

One possible explanation for the differing effects of HA on the $\mathrm{VL}$ activities of $\mathrm{P}^{-\mathrm{TiO}_{2}}$ and $\mathrm{Nf}-\mathrm{TiO}_{2}$ in phenol degradation and the photocurrent responses is that the amounts of HA adsorbed are different. An increase or decrease in HA adsorption would strengthen or weaken the favorable sensitizing effect of HA. The adsorption of HA on various catalysts was investigated; the results are shown in Fig. 3. The time to reach adsorption balance for $\mathrm{Nf}^{-\mathrm{TiO}_{2}}$ was about 40 min (Fig. 3(a)), slightly longer than those for $\mathrm{TiO}_{2}$ and $\mathrm{P}_{-} \mathrm{TiO}_{2}$ (less than $10 \mathrm{~min}$ ). However, the equilibrium concentrations of $\mathrm{HA}$ on $\mathrm{P}_{-} \mathrm{TiO}_{2}$ and $\mathrm{Nf}-\mathrm{TiO}_{2}$ were similar (Fig. 3(b)). The adsorption capacities at an initial concentration of $20 \mathrm{mg} / \mathrm{L} \mathrm{HA}$ were $(30.2 \pm 1.4)$ and $(29.9 \pm 0.1) \mathrm{mg} / \mathrm{g}$ for $\mathrm{P}_{-}-\mathrm{TiO}_{2}$ and $\mathrm{Nf}-\mathrm{TiO}_{2}$, respectively; these are slightly lower than that for $\left.\mathrm{TiO}_{2}(33.9 \pm 0.1) \mathrm{mg} / \mathrm{g}\right)$. The adsorption of $\mathrm{HA}$ on the oxide surface involves electrostatic interactions, ligand exchange, hydrophobic interactions, entropic effects, hydrogen 

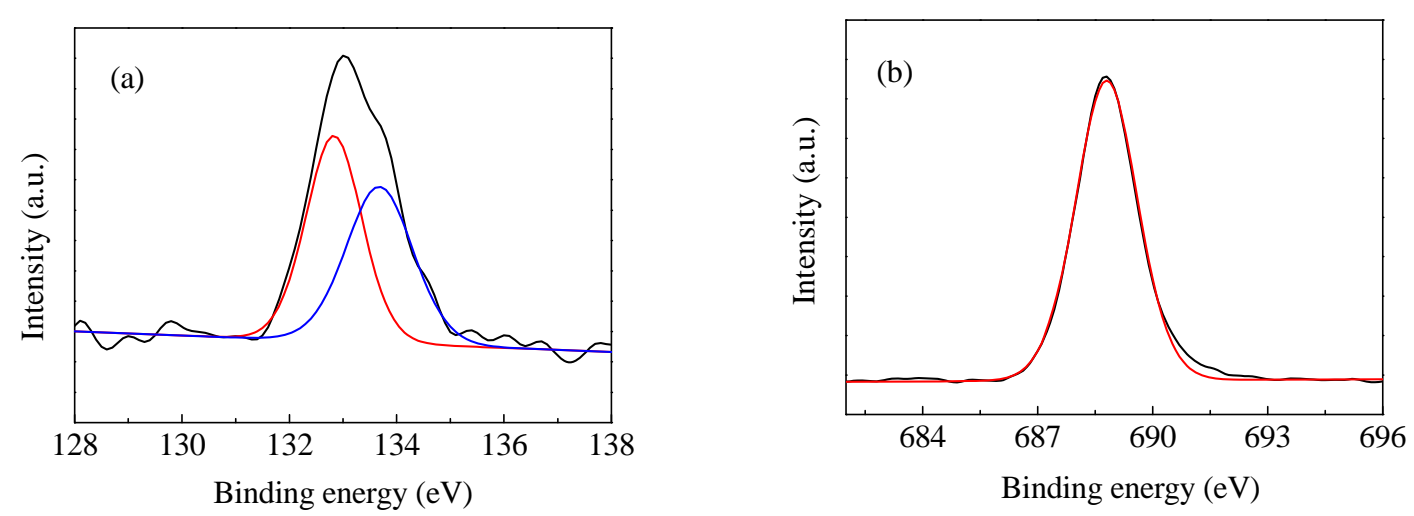

Fig. 2. P $2 p$ (a) and F $1 s$ (b) core-level XPS spectra for phosphate- and Nafion-modified $\mathrm{TiO}_{2}$.
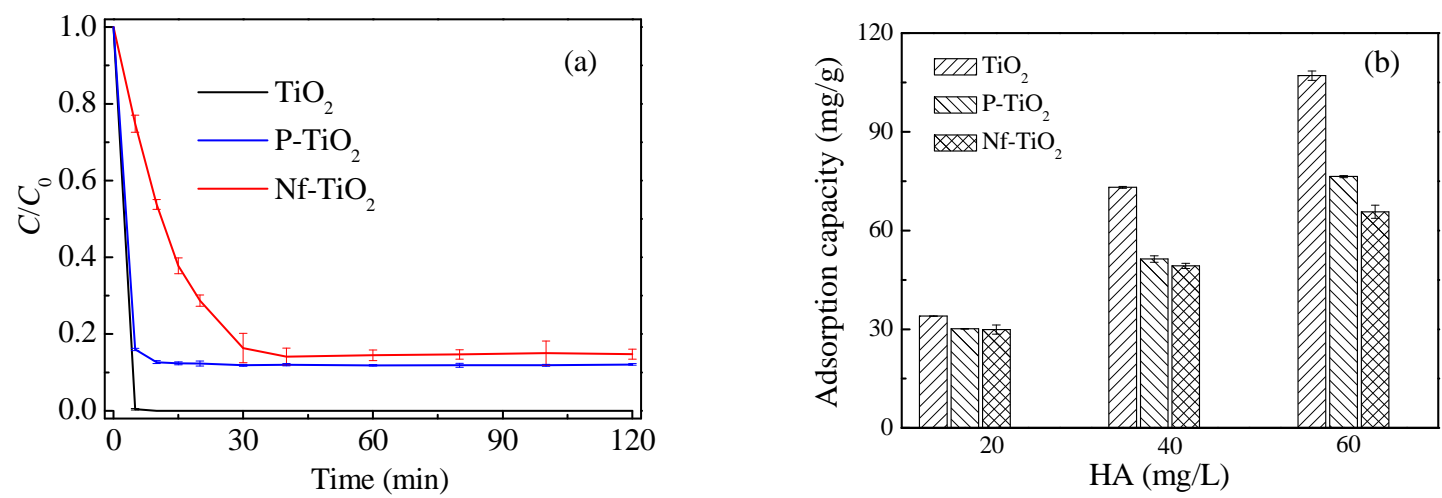

Fig. 3. Adsorption of $\mathrm{HA}$ on $\mathrm{TiO}_{2}, \mathrm{P}_{-} \mathrm{TiO}_{2}$, and Nf- $\mathrm{TiO}_{2}$. (a) Time dependence of $\mathrm{HA}$ adsorption (initial [HA] = $20 \mathrm{mg} / \mathrm{L}$ ); and (b) equilibrium adsorption capacity at various initial $\mathrm{HA}$ concentrations (initial $\mathrm{pH}=3.0$ ).

bonding, and cation bridging $[53,54]$. The modified $\mathrm{TiO}_{2}$ materials both had negative zeta potentials at the studied $\mathrm{pH}$ (Fig. S5), indicating similar electrostatic interactions between HA and the modified $\mathrm{TiO}_{2}$. However, phosphate modification would increase the hydrophilicity of the $\mathrm{TiO}_{2}$ surface and strengthen adsorption via ligand exchange or cation bridging. Nafion modification of $\mathrm{TiO}_{2}$ would enhance the hydrophobicity and improve hydrophobic interactions with $\mathrm{HA}$. Both modified $\mathrm{TiO}_{2}$ materials therefore had adsorption capacities similar to that of pristine $\mathrm{TiO}_{2}$ at a low initial HA concentration. At higher initial concentrations of $\mathrm{HA}$, the adsorption capacity of $\mathrm{TiO}_{2}$ was much higher than those of $\mathrm{P}^{-} \mathrm{TiO}_{2}$ and $\mathrm{Nf}-\mathrm{TiO}_{2}$. However, the amount of $\mathrm{HA}$ adsorbed on $\mathrm{Nf}^{-\mathrm{TiO}_{2}}$ was always lower than that on $\mathrm{P}-\mathrm{TiO}_{2}$, which indicates that the poor sensitizing effect of HA on $\mathrm{P}_{-} \mathrm{TiO}_{2}$ cannot be ascribed to blockage of HA adsorption by surface-modifying phosphate anions, and the better photocatalytic activity of $\mathrm{Nf}^{-\mathrm{TiO}_{2}}$ is irrelevant in terms of adsorption.

Three chemicals, namely FFA, BQ, and IPA, were used as scavengers for singlet oxygen, superoxide, and hydroxyl radicals, respectively. Because phenol degradation in the $\mathrm{P}^{-\mathrm{TiO}_{2}} / \mathrm{HA}$ suspension was poor, the effects of scavengers on phenol degradation in $\mathrm{TiO}_{2} / \mathrm{HA}$ and $\mathrm{Nf}-\mathrm{TiO}_{2} / \mathrm{HA}$ suspensions were investigated. Fig. 4 shows that addition of $\mathrm{BQ}$ significantly decreased the phenol degradation efficiencies of both the $\mathrm{TiO}_{2}$ and $\mathrm{Nf}^{-\mathrm{TiO}_{2}}$ systems, suggesting that superoxide radicals are the main ROS in HA-sensitized $\mathrm{TiO}_{2}$ photocatalysis. The mechanism can be described by the sequential one-electron reactions shown in Eqs. (1)-(4). Under VL irradiation, electrons are generated by excitation of $\mathrm{HA}$ (Eq. (1)) and transferred to $\mathrm{TiO}_{2}$ (Eq. (2)). The electrons are then scavenged by oxygen, producing superoxide radicals (Eq. (3)) and then $\mathrm{H}_{2} \mathrm{O}_{2}$ (Eq. (4)). Recombination can also take place when electrons are trapped by positively charged HA radicals (Eq. (5)). Unlike UV irradiation, which can induce band gap excitation of electrons and produce holes that are strong enough oxidants to produce $\cdot \mathrm{OH}$, the active species produced by VL irradiation of sensitized $\mathrm{TiO}_{2}$ originate exclusively from electron transfer, and superoxide radicals are the dominant ROS for organic degradation.

$$
\mathrm{HA}+h v(\lambda>420 \mathrm{~nm}) \rightarrow \mathrm{HA}^{*} \text { (Excitation) }
$$

$\mathrm{HA}^{*}+\mathrm{hu}+\mathrm{TiO}_{2} \rightarrow \mathrm{HA}^{-+}+\mathrm{TiO}_{2}\left(\mathrm{e}^{-}\right)$(Electron injection) (2)

$\mathrm{TiO}_{2}\left(\mathrm{e}^{-}\right)+\mathrm{O}_{2} \rightarrow \mathrm{TiO}_{2}+\mathrm{O}_{2}{ }^{--}$(Electron scavenging)

$$
\mathrm{O}_{2}^{\cdot-} \stackrel{\mathrm{H}^{+}}{\rightarrow} \mathrm{HO}_{2}^{\cdot} \stackrel{\mathrm{e}^{-}+\mathrm{H}^{+}}{\longrightarrow} \mathrm{H}_{2} \mathrm{O}_{2}
$$

$$
\mathrm{HA}^{\bullet+}+\mathrm{TiO}_{2}\left(\mathrm{e}^{-}\right) \rightarrow \mathrm{HA} \text { (Recombination) }
$$

$4 \mathrm{TiO}_{2}\left(\mathrm{e}^{-}\right)+\mathrm{O}_{2}+4 \mathrm{H}^{+} \rightarrow \mathrm{TiO}_{2}+2 \mathrm{H}_{2} \mathrm{O}$

$$
\mathrm{HA}^{*}+h v \rightarrow{ }^{3} \mathrm{HA}^{*} \text { (Energy transfer) }
$$

$$
\mathrm{O}_{2}+{ }^{3} \mathrm{HA}^{*} \rightarrow \mathrm{HA}+{ }^{1} \mathrm{O}_{2} \text { (Energy transfer) }
$$

EPR spectroscopy was used to confirm the production of $\mathrm{O}_{2}{ }^{--}$in the illuminated suspensions. Fig. 5(a) shows that six characteristic peaks from DMPO- $\mathrm{O}_{2}{ }^{--}$spin adducts were clearly 

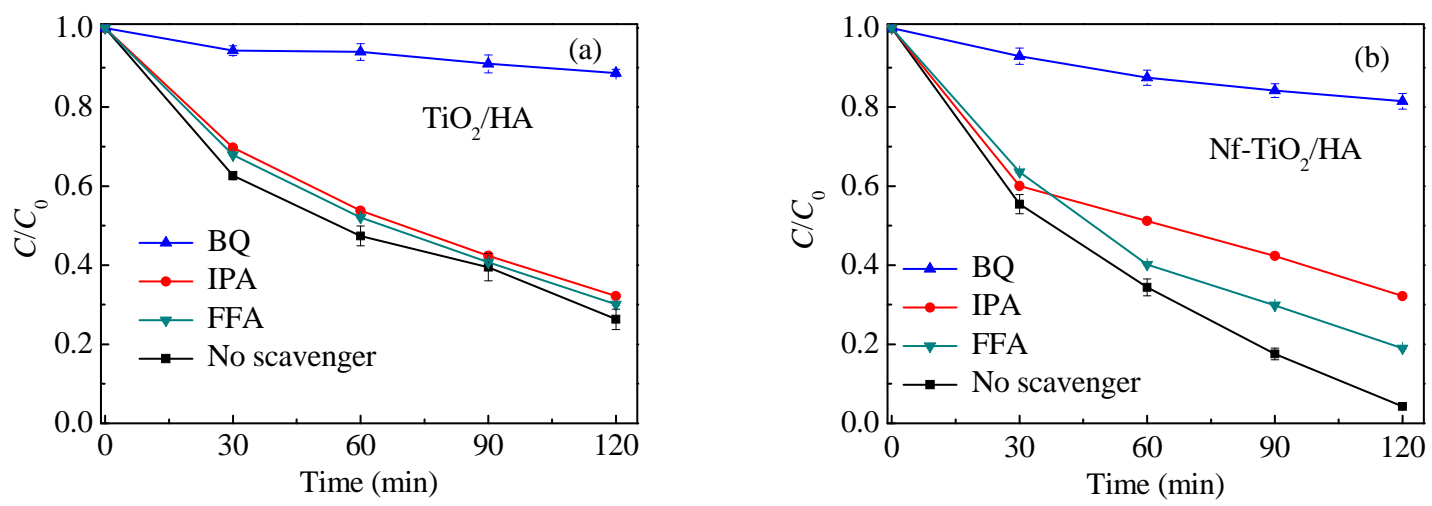

Fig. 4. Effects of scavengers on VL degradation of phenol in presence of $20 \mathrm{mg} / \mathrm{L} \mathrm{HA}$ on $\mathrm{TiO}_{2}$ (a) and $\mathrm{Nf}^{-\mathrm{TiO}_{2}}$ (b) $([\mathrm{phenol}]=10 \mathrm{mg} / \mathrm{L} ; \mathrm{initial} \mathrm{pH}=3.0$; $\lambda>420 \mathrm{~nm}$ ).
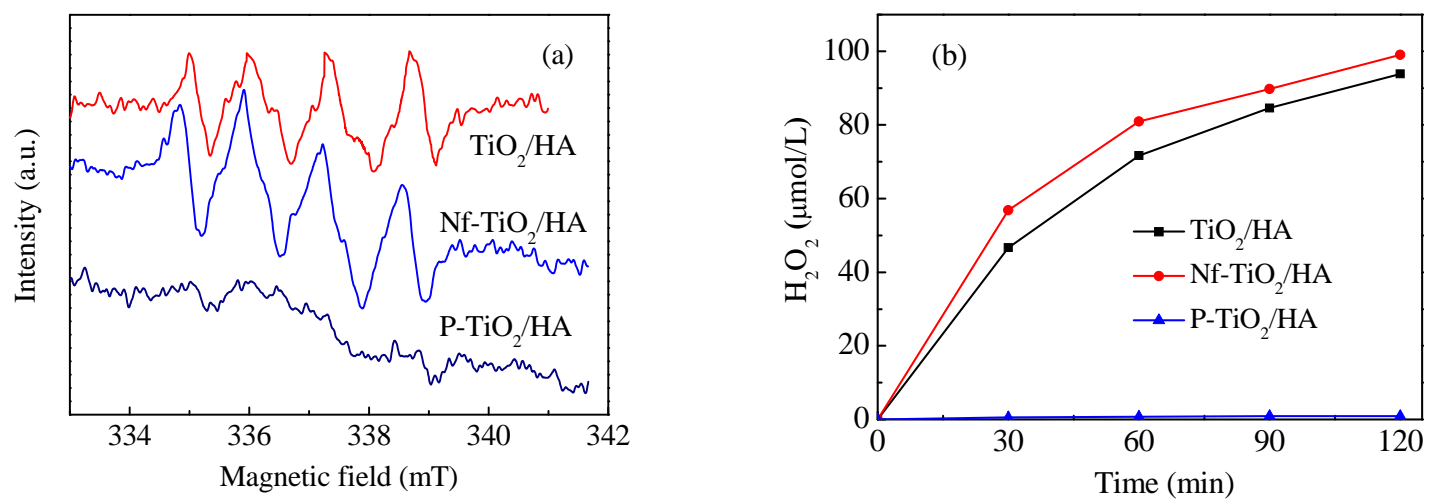

Fig. 5. (a) Ambient-temperature EPR spectra of DMPO- $\mathrm{O}_{2}{ }^{--}$in illuminated suspensions with $20 \mathrm{mg} / \mathrm{L} \mathrm{HA}$; (b) photocatalytic generation of $\mathrm{H}_{2} \mathrm{O}_{2}$ in $\mathrm{TiO}_{2} / \mathrm{HA}, \mathrm{Nf}-\mathrm{TiO}_{2} / \mathrm{HA}$, and $\mathrm{P}-\mathrm{TiO}_{2} / \mathrm{HA}$ suspensions under VL irradiation $\left([\mathrm{HA}]_{0}=20 \mathrm{mg} / \mathrm{L}\right.$, initial $\left.\mathrm{pH}=3.0\right)$.

observed for the $\mathrm{TiO}_{2} / \mathrm{HA}$ and $\mathrm{Nf}-\mathrm{TiO}_{2} / \mathrm{HA}$ suspensions; however, no signal was detected for $\mathrm{P}_{-} \mathrm{TiO}_{2} / \mathrm{HA}$, which indicates the absence of $\mathrm{O}_{2}{ }^{--}$in the $\mathrm{P}_{-} \mathrm{TiO}_{2} / \mathrm{HA}$ suspension. Because $\mathrm{O}_{2}{ }^{--}$is the photochemical precursor of $\mathrm{H}_{2} \mathrm{O}_{2}$ and accumulation of $\mathrm{H}_{2} \mathrm{O}_{2}$ formed as an intermediate is always observed in photocatalysis, the concentrations of $\mathrm{H}_{2} \mathrm{O}_{2}$ in different photocatalytic systems were monitored using the DPD-POD method to further investigate the effect of $\mathrm{HA}$ sensitization of modified $\mathrm{TiO}_{2}$. The concentration of $\mathrm{H}_{2} \mathrm{O}_{2}$ was negligible in the illuminated $\mathrm{P}^{-\mathrm{TiO}_{2}} / \mathrm{HA}$ suspension, but was significant in the other two suspensions (Fig. 5(b)). After VL irradiation for $120 \mathrm{~min}$, the concentration of $\mathrm{H}_{2} \mathrm{O}_{2}$ had increased to 93 and $99 \mu \mathrm{mol} / \mathrm{L}$ for the $\mathrm{TiO}_{2} / \mathrm{HA}$ and $\mathrm{Nf}-\mathrm{TiO}_{2} / \mathrm{HA}$ suspensions, respectively. The amount of $\mathrm{H}_{2} \mathrm{O}_{2}$ in the $\mathrm{P}^{-\mathrm{TiO}_{2}} / \mathrm{HA}$ suspension was almost negligible, indicating low production of $\mathrm{O}_{2}{ }^{--}$, in agreement with the EPR analysis. The results suggest that $\mathrm{P}^{-\mathrm{TiO}_{2}}$ enabled the ORR to proceed via a direct four-electron pathway (Eq. (6)). This can be rationalized by assuming that the HA molecules and anchored phosphate anions served as proton relays to provide adequate localized protons for proton-coupled electron transfer in a multi-electron ORR [55]. Although singlet oxygen could be generated through energy transfer processes (Eqs. (7) and (8)), its contribution to organic degradation is limited because of its low quantum yield under VL irradiation and relatively

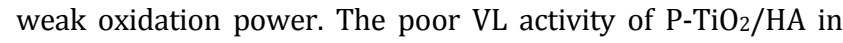
phenol degradation and the light-source-dependent effect of $\mathrm{HA}$ on $\mathrm{P}_{-} \mathrm{TiO}_{2}$ photocatalysis can therefore be explained.

The production of a significant amount of $\mathrm{H}_{2} \mathrm{O}_{2}$ in the illuminated $\mathrm{Nf}-\mathrm{TiO}_{2} / \mathrm{HA}$ suspension indicates that ORR on this catalyst followed the single-electron pathway. Moreover, the phenol degradation activity of $\mathrm{Nf}^{-} \mathrm{TiO}_{2} / \mathrm{HA}$ was better than that of $\mathrm{TiO}_{2} / \mathrm{HA}$, although less $\mathrm{HA}$ was adsorbed on $\mathrm{Nf}^{-\mathrm{TiO}_{2}}$ than on $\mathrm{TiO}_{2}$. The improved electron transfer efficiency was investigated by measuring the conductivities of the catalysts. Fig. 6(a) shows Mott-Schottky curves for the three electrodes. For n-type semiconductors such as $\mathrm{TiO}_{2}$, the relationship between the depletion layer capacitance $\left(C_{\mathrm{sc}}\right)$ and applied bias $(E)$ can be described by Eq. (9),

$$
1 / C_{\mathrm{sc}}^{2}=2\left(E-E_{\mathrm{FB}}-k T / e\right) /\left(\varepsilon_{0} \varepsilon_{\mathrm{r}} N_{\mathrm{D}} A^{2}\right)
$$

wherein $e$ is the electronic charge, $\varepsilon_{0}$ is the permittivity of a vacuum, $\varepsilon_{\mathrm{r}}$ is the dielectric constant of $\mathrm{TiO}_{2}, A$ is the contact area of the electrode in the electrolyte, $E_{\mathrm{FB}}$ is the flat-band potential of the semiconductor, and $N_{\mathrm{D}}$ is the carrier (electrons for n-type) density. The term $k T / e$ can be ignored because of its low value. The $E_{\mathrm{FB}}$ and $N_{\mathrm{D}}$ of the semiconductor can be obtained from the slope and intercept, respectively, of the fitted curves. The fitted equations in Fig. 6(a) show that the estimated $E_{\mathrm{FB}}$ 

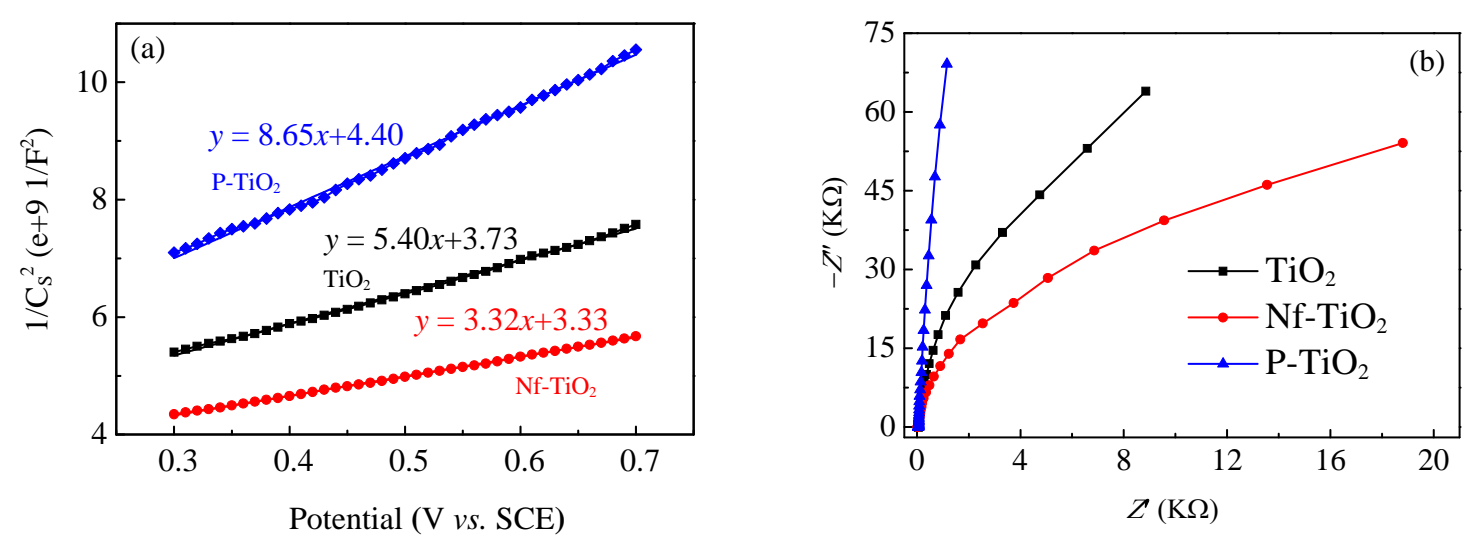

Fig. 6. Mott-Schottky (a) and EIS (b) plots for $\mathrm{TiO}_{2}, \mathrm{P}_{-} \mathrm{TiO}_{2}$, and $\mathrm{Nf}-\mathrm{TiO}_{2}$ electrodes.

potentials for $\mathrm{TiO}_{2}$, Nf- $-\mathrm{TiO}_{2}$, and $\mathrm{P}_{-}-\mathrm{TiO}_{2}$ were $-0.54,-0.85$, and $-0.36 \mathrm{~V}$, respectively, vs the normal hydrogen electrode at $\mathrm{pH}=$ 7. Nafion modification led to clear cathodic shifts of the energy band positions, whereas phosphate modification had the opposite effect on energy band shifts. Electron transfer is expected to be facilitated when the semiconductor has more cathodic conduction band positions. The $N_{\mathrm{D}}$ values can be compared based on the curve slopes. P- $\mathrm{TiO}_{2}$ had the lowest $N_{\mathrm{D}}$ value, about $62.4 \%$ of that for $\mathrm{TiO}_{2}$, and $\mathrm{Nf}-\mathrm{TiO}_{2}$ had the highest $N_{\mathrm{D}}$, about $62 \%$ higher than that for $\mathrm{TiO}_{2}$. The increased $N_{\mathrm{D}}$ for $\mathrm{Nf}-\mathrm{TiO}_{2}$ improves the electron mobility and reduces electron resistance; this is supported by the EIS results (Fig. 6(b)). Nyquist plots for $\mathrm{TiO}_{2}$ and the modified $\mathrm{TiO}_{2}$ materials were obtained at $0.2 \mathrm{~V}$ vs the standard calomel electrode. The charge transfer resistance $\left(R_{\mathrm{ct}}\right)$, which is the resistance to electron transfer from the electrode to the electrolyte, directly correlates with the semicircle diameter at high frequencies. The EIS plots show that the $\mathrm{Nf}^{-\mathrm{TiO}_{2}}$ electrode had the lowest $\mathrm{R}_{\mathrm{ct}}$ and $\mathrm{P}^{-\mathrm{TiO}_{2}}$ had the highest $R_{\mathrm{ct}}$. This indicates that resistance to electron transfer through the solid/liquid interface was lowest for the $\mathrm{Nf}_{-} \mathrm{TiO}_{2}$. This would result in fewer possibilities for charge recombination and higher efficiency of ROS generation and pollutant degradation.

\section{Conclusions}

In this study, the sensitizing effects of $\mathrm{HA}$ on $\mathrm{P}_{-} \mathrm{TiO}_{2}$ and $\mathrm{Nf}-\mathrm{TiO}_{2}$ were investigated. The results indicate the following. (1) Sensitization by HA was negligible for $\mathrm{P}_{-} \mathrm{TiO}_{2}$, and active species such as superoxide radicals were not observed in the illuminated suspension; this can be ascribed to a possible direct four-electron ORR. (2) Sensitization by HA was strong for $\mathrm{Nf}-\mathrm{TiO}_{2}$; the reaction rate constant for phenol degradation in the presence of $20 \mathrm{mg} / \mathrm{L} \mathrm{HA}$ was 7.8 times that in the absence of HA; this can be attributed to a cathodic shift of the flat-band potential, increased electron density, and decreased resistance between $\mathrm{TiO}_{2}$ and the electrolyte after modification with Nafion. The results of the present work suggest that phosphate modification could be used to reduce the photochemical activity of $\mathrm{TiO}_{2}$ nanoparticles in water containing NOM, and the VL activity of sensitized $\mathrm{TiO}_{2}$ can be further improved by tuning the semiconductor properties through surface modification.

\section{References}

[1] U. I. Gaya, A. H. Abdullah, J. Photochem. Photobiol. C, 2008, 9, 1-12.

[2] X. H. Guan, J. S. Du, X. G. Meng, Y. K. Sun, B. Sun, Q. H. Hu, J. Hazard. Mater., 2012, 215-216, 1-16.

[3] H. R. Dong, G. M. Zeng, L. Tang, C. Fan, C. Z. Zhang, X. X. He, Y. He, Water Res., 2015, 79, 128-146.

[4] M. C. Wen, S. S. Zhang, W. R. Dai, G. S. Li, D. Q. Zhang, Chin. J. Catal., 2015, 36, 2095-2102.

[5] Y. Du, D. D. Tang, G. K. Zhang, X. Y. Wu, Chin. J. Catal., 2015, 36, 2219-2228.

[6] X. F. Wang, R. Yu, K. Wang, G. Q. Yang, H. G. Yu, Chin. J. Catal, 2015, $36,2211-2218$.

[7] M. C. Long, L. H. Zheng, Chin. J. Catal., 2017, 38, 617-624.

[8] M. C. Long, W. M. Cai, Nanoscale, 2014, 6, 7730-7742.

[9] J. X. Low, J. G. Yu, M. Jaroniec, S. Wageh, A. A. Al-Ghamdi, Adv. Mater., 2017, 29, 1601694.

[10] M. S. Akple, J. X. Low, Z. Y. Qin, S. Wageh, A. A. Al-Ghamdi, J. G. Yu, S. W. Liu, Chin. J. Catal., 2015, 36, 2127-2134.

[11] Y. F. Li, W. P. Zhang, X. Shen, P. F. Peng, L. B. Xiong, Y. Yu, Chin. J. Catal., 2015, 36, 2229-2236.

[12] Y. K. Ooi, L. Yuliati, S. L. Lee, Chin. J. Catal., 2016, 37, 1871-1881.

[13] C. L. Zhang, H. Hua, J. L. Liu, X. Y. Han, Q. P. Liu, Z. D. Wei, C. B. Shao, C. G. Hu, Nano-Micro Lett., 2017, 9, 49-61.

[14] E. L. Cates, Environ. Sci. Technol., 2017, 51, 757-758.

[15] C. P. Sajan, S. Wageh, A. A. Al-Ghamdi, J. G. Yu, S. W. Cao, Nano Res., 2016, 9, 3-27.

[16] H. Park, Y. Park, W. Kim, W. Choi, J. Photochem. Photobio. C, 2013, $15,1-20$.

[17] M. Long, L. Zheng, B. Tan, H. Shu, Appl. Surf. Sci., 2016, 386, 434-441.

[18] S. G. Kumar, K. S. R. K. Rao, Appl. Surf. Sci., 2017, 391, 124-148.

[19] J. X. Low, B. Cheng, J. G. Yu, Appl. Surf. Sci., 2017, 392, 658-686.

[20] J. Wen, X. Li, W. Liu, Y. Fang, J. Xie, Y. Xu, Chin. J. Catal., 2015, 36, 2049-2070.

[21] L. Q. Jing, Y. Cao, H. Q. Cui, J. R. Durrant, J. W. Tang, D. N. Liu, H. G. Fu, Chem. Commun., 2012, 48, 10775-10777.

[22] K. Pan, Z. Y. Liu, J. Q. Hu, J. Li, Z. H. Li, D. Li, Y. Liu, M. Liu, J. H. Li, D. J. Wang, Y. B. Yu, T. J. Li, Chem. Res. Chin. Univ., 2005, 21, 360-364.

[23] Z. Long, G. R. Deng, C. P. Liu, J. J. Ge, W. Xing, S. H. Ma, Chin. J. Catal., 2016, 37, 988-993. 


\title{
Graphical Abstract
}

Chin. J. Catal., 2017, 38: 2076-2084 doi: 10.1016/S1872-2067(17)62951-6

Humic acid-mediated visible-light degradation of phenol on phosphate-modified and Nafion-modified $\mathrm{TiO}_{2}$ surfaces

Longhui Zheng, Xiaojuan Yu, Mingce Long *, Qilin Li

Shanghai Jiao Tong University, China; Rice University, United States

Sensitization by humic acid was weaker for phosphate-modified $\mathrm{TiO}_{2}$ than for Nafion-modified $\mathrm{TiO}_{2}$. This is ascribed to an altered oxygen reduction pathway in the former case, and facilitated charge transfer in the latter case.
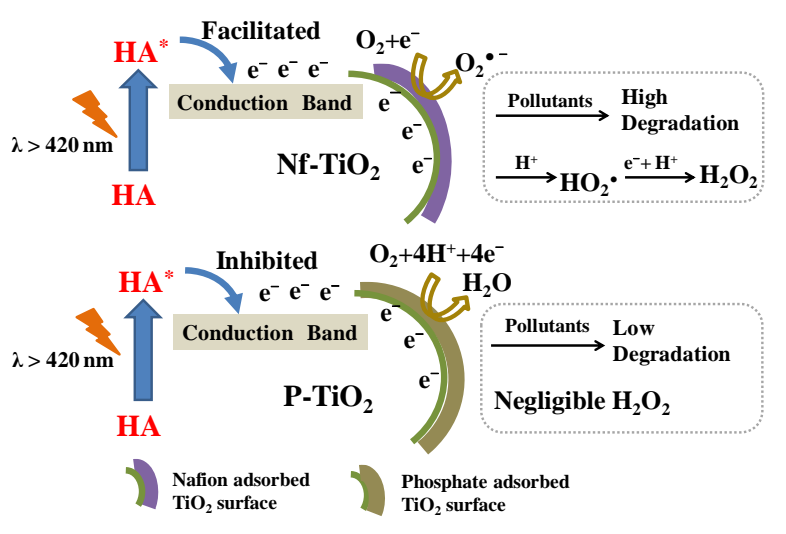

[24] J. Park, J. Yi, T. Tachikawa, T. Majima, W. J. Choi, J. Phys. Chem. Lett., 2010, 1, 1351-1355.

[25] X. L. Zheng, J. P. Song, T. Ling, Z. P. Hu, P. F. Yin, K. Davey, X. W. Du, S. Z. Qiao, Adv. Mater., 2016, 28, 4935-4942.

[26] W. Y. Wang, Y. Ku, Colloids Surf. A, 2007, 302, 261-268.

[27] M. S. Vohra, K. Tanaka, Environ. Sci. Technol, 2001, 35, 411-415.

[28] K. T. Chen, C. S. Lu, T. H. Chang, Y. Y. Lai, T. H. Chang, C. W. Wu, C. C. Chen, J. Hazard. Mater., 2010, 174, 598-609.

[29] V. Arun, K. R. Sankaran, J. Electroanal. Chem., 2016, 769, 35-41.

[30] H. Park, W. Choi, J. Phys. Chem. B, 2005, 109, 11667-11674.

[31] H. Sheng, Q. Li, W. H. Ma, H. W. Ji, C. C. Chen, J. C. Zhao, Appl. Catal. $B, 2013,138-139,212-218$.

[32] M. Long, J. Brame, F. Qin, J. Bao, Q. Li, P. J. Alvarez, Environ. Sci. Technol., 2017, 51, 514-521.

[33] D. Zhao, C. C. Chen, Y. F. Wang, H. W. Ji, W. H. Ma, L. Zang, J. C. Zhao, J. Phys. Chem. C, 2008, 112, 5993-6001.

[34] Y. Cao, L. Q. Jing, X. Shi, Y. B. Luan, J. R. Durrant, J. W. Tang, H. G. Fu, Phys. Chem. Chem. Phys., 2012, 14, 8530-8536.

[35] C. Liu, F. Raziq, Z. J. Li, Y. Qu, A. Zada, L. Q. Jing, Chin. J. Catal., 2017, 38, 1072-1078.

[36] J. Brame, M. C. Long, Q. Li, P. Alvarez, Water Res., 2015, 84, 362-371.

[37] J. Brame, M. C. Long, Q. Li, P. Alvarez, Water Res., 2014, 60, 259-266.

[38] Y. Lee, U. von Gunten, Water Res., 2010, 44, 555-566.

[39] T. E. Doll, F. H. Frimmel, Water Res., 2005, 39, 403-411.

[40] M. Fujii, E. Otani, Water Res., 2017, 123, 642-654.
[41] S. Li, J. Y. Hu, J. Hazard. Mater., 2016, 318,134-144.

[42] A. Pajares, M. Bregliani, J. Natera, S. Criado, S. Miskoski, J. P. Escalada, N. A. García, J. Photochem. Photobiol. A, 2011, 219, 84-89.

[43] Y. Li, J. F. Niu, E. X. Shang, J. C. Crittenden, Water Res., 2016, 98, 9-18.

[44] Y. Chen, K. Zhang, Y. G. Zuo, Sci. Total Environ., 2013, 463-464, 802-809.

[45] P. Calza, D. Vione, C. Minero, Sci. Total Environ., 2014, 493, 411-418.

[46] E. Lee, C. M. Glover, F. L. Rosario-Ortiz, Environ. Sci. Technol,, 2013, 47, 12073-12080.

[47] K. Vinodgopal, P. V. Kamat, Environ. Sci. Technol., 1992, 26, 1963-1966.

[48] C. S. Uyguner, M. Bekbolet, Catal. Today, 2005, 101, 267-274.

[49] C. Wang, M. C. Long, B. H. Tan, L. H. Zheng, J. Cai, J. J. Fu, Electrochim. Acta, 2017, 250, 108-116.

[50] H. Bader, V. Sturzenegger, J. Hoigné, Water Res., 1988, 22, 1109-1115.

[51] H. T. Liu, H. Gao, M. C. Long, H. Y. Fu, P. J. J. Alvarez, Q. L. Li, S. R. Zheng, X. L. Qu, D. Q. Zhu, Environ. Sci. Technol, 2017, 51, 6877-6886.

[52] S. Kim, W. Choi, J. Phys. Chem. B, 2005, 109, 5143-5149.

[53] B. H. Gu, J. Schmitt, Z. H. Chen, L. Y. Liang, J. F. McCarthy, Environ. Sci. Technol., 1994, 28, 38-46.

[54] S. H. Kang, B. S. Xing, Langmuir, 2008, 24, 2525-2531.

[55] H. Sheng, H. W. Ji, W. H. Ma, C. C. Chen, J. C. Zhao, Angew. Chem. Int. Ed., 2013, 52, 9686-9690.

\section{磷酸根和Nafion修年 $\mathrm{TiO}_{2}$ 表面腐植酸调控的可见光催化降解苯酚性能}

\author{
郑龙辉 ${ }^{\mathrm{a}}$, 于晓娟 ${ }^{\mathrm{a}}$, 龙明策 ${ }^{\mathrm{a}, \mathrm{b},{ }^{*}}$, 李琪琳 ${ }^{\mathrm{c}}$ \\ a 海交通大学环境科学与工程学院, 上海200240, 中国 \\ ${ }^{\mathrm{b}}$ 上海交通大学薄膜与微细技术教育部重点实验室, 上海200240, 中国 \\ ${ }^{\mathrm{c}}$ 莱斯大学土木与环境工程系, 德克萨斯休斯敦77005, 美国
}

摘要: 光催化水处理技术有望成为一种有效去除水中难降解有机污染物的方法. 尽管人们已经研制了大量的新型光催化 剂, 但在环境应用中纳米 $\mathrm{TiO}_{2}$ 仍是最受欢迎的催化剂. 由于光催化反应在表面发生, 反应动力学主要取决于 $\mathrm{TiO}_{2}$ 的表面性 质, 因此, 表面修饰是调控 $\mathrm{TiO}_{2}$ 光催化反应的重要手段, 其中 Nafion和磷酸根表面修饰 $\mathrm{TiO}_{2}$ 简单可行. Nafion修饰可以通过 
离子交换吸附富集阳离子底物提高光催化降解效率; 而磷酸根修饰则可以增强对弱吸附底物的降解活性. 另一方面, 水 中共存的天然有机物(NOM)例如腐植酸(HA)将抑制 $\mathrm{TiO}_{2}$ 光催化降解目标污染物的活性, 同时又将通过光敏化诱导可见光 催化性能. 因此, 研究如何调控NOM对光催化反应的影响将有助于光催化水处理技术的工程应用. 本文以HA作为代表性 的NOM，研究了磷酸根和Nafion两种不同修饰方法对 $\mathrm{HA}$ 敏化 $\mathrm{TiO}_{2}$ 性能的影响规律.

可见光降解苯酚的实验结果表明, $\mathrm{HA}$ 的敏化可以提高 $\mathrm{TiO}_{2}$ 可见光降解苯酚的效率. 磷酸根修饰 $\mathrm{TiO}_{2}$ 抑制了 $\mathrm{HA}$ 的敏化 作用, 而Nafion修饰则增强了 HA的敏化作用并提高可见光降解苯酚的活性. 当 $\mathrm{HA}$ 浓度为 $20 \mathrm{mg} / \mathrm{L}$ 时, $\mathrm{Nafion}$ 修饰 $\mathrm{TiO}_{2}$ 降解 $10 \mathrm{mg} / \mathrm{L}$ 苯酚的反应速率常数由 $(0.003 \pm 0.001) \mathrm{min}^{-1}$ 提高至 $(0.025 \pm 0.003) \mathrm{min}^{-1}$. 表面修饰引起的反应活性差异不能归因于 $\mathrm{HA}$ 的吸附容量的变化, 因为吸附实验表明在光催化反应条件下, 两种表面修饰的 $\mathrm{TiO}_{2}$ 对 $\mathrm{HA}$ 的吸附容量并无显著差异. 添 加不同的自由基捕获剂发现, $\mathrm{HA}$ 敏化 $\mathrm{TiO}_{2}$ 及 Nafion修饰 $\mathrm{TiO}_{2}$ 降解苯酚的主要活性物质为超氧自由基, 而磷酸根修饰 $\mathrm{TiO}_{2}$ 的光催化反应中并没有超氧自由基. 通过检测超氧自由基的电子自旋共振信号进一步证实了这一点. 测试发现, 光催化 反应中Nafion修饰 $\mathrm{TiO}_{2}$ 产生的 $\mathrm{H}_{2} \mathrm{O}_{2}$ 增加, 而磷酸根修饰的几乎不产生 $\mathrm{H}_{2} \mathrm{O}_{2}$, 说明可能发生了四电子的氧还原反应. 莫特肖特基曲线(Mott-Schottky)的测试结果表明, Nafion修饰 $\mathrm{TiO}_{2}$ 的平带电位从 $-0.54 \mathrm{~V}$ 负移到 $-0.85 \mathrm{~V}$, 多数载流子电子的密度 提高了 $62 \%$. 电化学阻抗结果显示, Nafion修饰 $\mathrm{TiO}_{2}$ 具有较小的界面电子迁移阻抗. 这些变化有利于提高电子迁移速率, 抑制复合并增加超氧自由基的生成, 从而提高光催化性能. 因此对 $\mathrm{TiO}_{2}$ 进行恰当的表面修饰, 将有助于强化 $\mathrm{HA}$ 的敏化作 用, 并提高可见光催化降解目标有机污染物的活性.

关键词: 二氧化钛; 腐植酸; Nafion; 磷酸根; 表面修饰

收稿日期: 2017-10-09. 接受日期: 2017-10-30. 出版日期: 2017-12-05.

*通讯联系人. 电话: (021)54747354; 传真: (021)54740825; 电子信箱: long_mc@sjtu.edu.cn

基金来源：国家自然科学基金(21377084); 农业部公益性行业专项(201503107); 上海市国际合作基金(15230724600).

本文的全文电子版由Elsevier出版社在ScienceDirect上出版(http://www.sciencedirect.com/science/journal/18722067). 